\title{
UNDERSTANDING THE RIFT, THE (STILL) UNEASY BEDFELLOWS OF HISTORY AND ORGANIZATION STUDIES
}

\author{
Anna Greenwood \\ University of Nottingham, China
}

\section{Andrea Bernardi ${ }^{1}$}

Manchester Metropolitan University, UK

\begin{abstract}
Although the use of history has become increasingly discussed and more widely applied within organization studies (OS), its relevance for OS still remains far from centrally accepted. This paper historicises the relationship between sociology and history as a means of better understanding the tensions, perceived and real, that exist between history and organization studies. In particular we analyse three differences of epistemological standpoint (method, objectivity and usefulness) that are commonly seen as the foundation stones to incompatibility. Perhaps surprisingly for an analysis of apparent disciplinary differences, we find that these distinctions in terms of approach, once closely examined, are rarely clear-cut and historians and OS scholars are frequently closer in intention and method than they are distant. However, despite their large intersection of interests, we argue that important distinctions between the two fields should be acknowledged. Our contribution to the debates over the need for more historical approaches within OS therefore centrally rests on abandoning aspirations for fully integrative models of working together, in favour of cooperative modes that concede the fields' differences. This subtle shift of emphasis will, we believe, greatly benefit OS scholars who hope to include historical perspectives in their work
\end{abstract}

\footnotetext{
${ }^{1}$ Corresponding Author: Manchester Metropolitan University, Department of Management, Oxford Road, Manchester M15 6BH, UK Email: a.bernardi@mmu.ac.uk
} 


\section{INTRODUCTION AND OBJECTIVES}

Despite repeated calls in the last twenty-five years for the wider use of History within Organization Studies (OS) the dialogue between the two disciplines remains far from seamless. This paper considers why this tension has been so persistently hard to reconcile and makes suggestions for a more self-confident interdisciplinary workability in the future.

We make three contributions (one central and two supplementary) to current lively debates about the use of History within OS. First and foremost, while we wholeheartedly agree that there are many advantages in OS scholars and historians working together, we ultimately advocate accepting the key methodological differences between OS and History as a means of advancing cooperation between the two fields. The best kind of mutual understanding, we maintain, is one that accepts - dare we say even celebrates - key differences between the fields and actually abandons ideas of interdisciplinary integration.

Our first supplementary contribution additionally points towards the originality in this paper's authorship (and therefore approach) in that comes from the pens of both a historian and an organizational scholar and uses both historians and sociologists in its references. This bucks the dominant trend whereby cries for the greater use of History within the OS and management journals are weakened by references and bibliographies only citing other social scientists working in business or management schools and do not engage in depth with historians on their own terms. ${ }^{2}$ In short, we have tried to understand History from inside the discipline, by drawing on insights offered by an academic historian previously unconnected with OS. This ties in with our second supplementary contribution. This sort of paper is vitally needed in the modern academic world where Heads of Departments and Deans are constantly told to justify the wider relevance and impact of research. Both historians and OS researchers in this climate can benefit from demonstrating their cross-disciplinary willingness. Endeavours such as this one raise the profile of History in terms of demonstrating its wider applicability to the modern world and also allow OS scholars to improve the quality and quantity of their insights.

In the first section of the paper we set the research context by summarising some of the key ways that OS scholars have explored the utilisation of historical methods in the past quarter of a century. It becomes clear from the multiplicity of approaches covered in our brief survey that it is problematic to conceive of 'Organization Studies' or even 'Historical Organization Studies' (let alone 'History') as easily essentialised concepts. Nevertheless, we find it impossible to deny that certain generalised claims for disciplinary difference have been, and

\footnotetext{
${ }^{2}$ Work by Rowlinson and Kippling provide a welcome exception to this.
} 
continue to be, made. Whether these differences are real or illusory they nevertheless colour perceptions, and therefore practice, when OS scholars use History. This takes us to the second and third sections of the paper. In the second section we examine some of the major debates in the history of the relationship between History and Sociology, with the purpose of shedding some light on the evolution of arguments over the compatibility or incompatibility between the two disciplines. This leads us to then explore in the third part of our paper some of the deepest stereotypes of disciplinary difference. Here we focus upon three apparent rifts in approach that are recurrently debated: namely differences between in the fields in their ideas about method, objectivity and usefulness.

In performing our analysis we found that the alleged dissimilarities (then as now) between sociological purpose and method and historical purpose and method are subtle, blurred even, and rarely absolute. In exploring this culture of disciplinary difference, we found a number of straw men. So-called 'differences' of approach and practice once analysed in any detail seemed over-simplified. Indeed we found that the practices of scholars within OS and History indicated more shared points of interest than areas of fundamental discord.

This is good news and as the fourth section of our paper explores, we support many of the arguments made for the tangible improvements historical approaches can bring to the field of OS. However, rather than this confirmation of similarity giving us cause to join the rallying cries for closer integration, we come to another conclusion. Instead, in our final section (five) we argue that the very fact that these apparent and real discordances exist, and furthermore have regularly existed, is sufficient justification for the self-conscious maintenance of important distinctions between the two disciplines. As such, we propose that close cooperation not methodological integration is the most desirable pursuit for scholars within both OS and History departments.

We do not want to make historians out of OS scholars and historians do not need to be specialists in the adept application of OS theoretical models. These differences are good. They are what defines the disciplines, and they are what gives them their unique character and integrity. We find no contradiction in recommending a certain amount of disciplinary exclusivity of approach, but nevertheless pro-actively pushing forward the benefits of crossfertilization. 


\section{1) ORGANIZATION STUDIES AND HISTORY: A BRIEF OVERVIEW}

Organization Studies is 'the examination of how individuals construct organizational structures, processes, and practices and how these, in turn, shape social relations and create institutions that ultimately influence people' (Clegg and Bailey, 2008). Since the 1980s, however, OS has progressively been widening its scope of enquiry, beyond what we might generally categorise as typically sociological concerns. Increasingly new psychological and economic theories came to widen the discipline, such as Principal Agent Theory (Jensen and Meckling, 1976), Transaction Cost Theory (Williamson, 1985) or Decision Theory (Harrison and March, 1986). As part of this widening and deepening, by the end of the decade history too began to be a realm of interest, with the first critiques emerging that OS theories were predominantly based on 'time-free statements' (Gherardi, Strati, 1988). The turning point is often considered to have occurred in the late 1980s and early 1990s, with the publication of Zald's then provocative declaration that 'historians of organization and sociologists of organization need each other- badly' (Zald, 1989, p.101) an opinion extended and supplemented with the 1994 publication of Kieser's now well-known article on the importance of integrating historical method into organizational analysis (Kieser, 1994).

It is nowadays widely agreed that History can offer noteworthy usefulness to OS researchers, both in terms of enriching and deepening theoretical insights but also in terms of practically supplementing data (Booth and Rowlinson, 2006; Clark and Rowlinson, 2004; Stager, 2006, Zald, 1993, 2002). Several journals now exist exploring the potentialities of this interdisciplinarity: for example, Accounting, Business and Financial History, Accounting History, Business History, Business History Review, Financial History Review, Business and Economic History, Entreprises et Histoire, Journal of Management History, Management and Organizational History. This interest is also mirrored in new conference themes. For example, at the European Group for Organisational Studies (EGOS) colloquia, a Standing Working Group focussing on Historical Perspectives in Organization Studies has been recently initiated, similarly at the British Academy of Management (BAM) conferences. At the Academy of Management (AOM) conferences, the Management History division has, since 1971, been actively debating issues related to the topic. Most recently, this evolving relationship between OS and History was marked through the milestone publication of a retrospective examination of the state of the art debates between OS scholars and Historians (Wadwani and Bucheli, 2013).

Nonetheless, although these explorations have enhanced insights within OS, the relationship between the two disciplines continues to feel somewhat stilted and uneasy. This is 
perhaps most easily demonstrated by the fact that, 25 years after the debates were first opened, the topic of how History and OS should best work together is clearly as fertile a ground for debate as it has ever been. One of the reasons for this, we argue, is that there is no one single formulaic way to apply History to OS (which is not to say that such a formula would be desirable). Not only have OS scholars variously used History, but also they have diversely come to different conclusions over what 'doing History' actually constitutes. In short, the search for one definitive historical practice to underscore OS methods is increasingly recognised as unjustifiable. History means different things and has different emphases to different people and the application of it naturally achieves different ends for different scholars (O'Sullivan and Graham, 2010, p.785). Indeed, as we mention later, History in fact prides itself on being a discipline untethered to methodology. This is not to say that historians do not regularly use different methodological tools to construct their arguments, but rather that historians, in general, prefer not to explicitly describe their methods within their research papers.

It is beyond the confines of this paper to trace this complex dialogue between History and OS more than relatively quickly; not least as this task has been performed more than adequately elsewhere (Clark \& Rowlinson, 2004; Rowlinson \& Hassard, 2011). Nevertheless, it is useful to recap who the chief groups of OS scholars who have taken heed of temporal dimensions are. Perhaps most famously prominent is the work of Alfred Chandler, latterly Professor of Business History at Harvard Business School and undoubtedly the most frequently cited historian of organizations (1977, 1990, 1998).

A very different contribution can be identified as that made by scholars such as Larry Greiner. This is an approach that examined models of organizational growth seeing organizational changes over the long-term perspective (Greiner, 1972). Author of a classic paper published by Harvard Business Review in 1972 and widely quoted ever since, Greiner, was not interested in using historical method, but rather focused on the development of a descriptive evolutionary model.

Supplementing and extending the work of these scholars looking at the foundations of the histories of businesses have been those who have historically analysed the various theoretical concepts of business and management that have emerged within specific national and temporal contingencies (Costea et al., 2006, Engwall, 1992; Shenav, 1999, Spector, 2006). Loosely linked to this group are those who have shown themselves to be interested in theoretical developments, but from a different angle, self-reflecting on OS as a young discipline and thereby unravelling the lessons learnt from its own disciplinary history and its on-going institutionalization (Clegg and Higgins, 1987, Davis, 2010; Hinings, 2010; Hoskin, 2004, 
Newton, 2010, Tadajewski 2009). Recent works have additionally advocated the need for historical re-interpretations, either recommending scholars to go back to the works of classical authors such as McGregor, Weber, Chandler and Braverman (Stager, 2006) or revisiting some of the key classic texts or experiments (for example Hawthorne in the 1920s), or the acts or thoughts of key protagonists, innovatively paying new attention to historicising them in the context of the influences and contingencies they faced at the time (Bruce and Nyland, 2011, Barratt, 2011; Bruce, 2006).

Another good example of how History and OS can work together is a group of studies examining historical events such as genocide or disasters, such as those which occurred with the Challenger spacecraft or in Chernobyl) (Starbuck and Milliken 1988; Vaughan 1996, Stokes and Yiannis, 2010). These works are not merely historical analyses, but also introduce the importance of reading these events as organisational phenomena, rather than reducing them to individual mistakes or the results of technical failures. Using these sorts of interpretations, for example, the explosion of the Challenger shuttle was not purely caused by a wrongly designed component, it was also the outcome of failures in the broader organisational and decisionmaking processes (Stokes and Yiannis, 2010, p. 463). In short, the disaster should be seen as entirely embedded in the organisational construction of meanings and events at that time.

Additionally, we should allude to the emergence of other fields, perhaps not so obviously based on empirical historical method in their orientation, but nevertheless interested in mapping both development and stasis over time within organizations. Particularly important here are works on population ecology that use a demographic (Carroll and Hannan 2000) and Darwinist (Hannan and Freeman 1977) analysis of organizations to emphasise the different environmental conditions in which organizational forms are conceived and exist. Similarly bracketed could be the subfield of Institutionalism. This is the school that has become interested in organizational path dependence (Beckman and Burton, 2008; David, 1985; Sydow, Schreyögg and Koch, 2009; Vergne and Durand, 2011; Schreyögg et al., 2011; Üsdiken et al., 2011), this approach has been particularly important in examining the role of (changing) culture(s) particularly in terms of changing the expectations of normativity in the dynamics of institutions (Bourdieu, 1990; Powell and DiMaggio, 1991; Scott, 2008). Although Institutionalism might be seen by many as the most 'social scientific' applications of History within OS, nevertheless, the idea to capture the whole, rather than part of the wider societal landscape in which ideas, institutions evolve has some similarities with the Annales tradition of 'total' history to which we will later return (e.g. Bloch, 1924 and Braudel, 1949). Although not currently a popular approach, we can clearly see how historians might easily adopt 
institutional methods as part of their methodological tool kits when constructing arguments over why society and institutions worked in particular ways.

Last, but by no means least, some concise mention should be made of the influences of literary theory and post-modern historical epistemology (most pointedly Foucault) on OS, which since the 1960s became part of the essential toolkit of many historians when doing their research. Particularly fashionable in this regard are works based on the perspective of storytelling and the social construction of reality and reflexivity (Berger and Luckmann, 1966; Cunliffe et al., 2004; Czarniawska, 1998; Douglas, 1987; Foster et al., 2011; Wolfram Cox and Hassard, 2007; Ybema, 2010), or the numerous works that use Foucaultian explanatory systems to explicate the dynamics behind the stratification of society and its institutions, particularly in terms of the deployment of power and associated meanings and consequences (Clegg, 1998; Burrell 1988; Hassard, 1993; Mckinlay, 2006). This interest within OS mirrors the large amount of historical work that utilizes Foucault - to the point where almost every modern historian seems to have a position vis à vis the issues raised by Foucaultian conceptions of power and its uses. But despite an abundance of attention, it would be wrong to imagine that Foucaultian theory was without criticism. OS scholars such as Carter, Mckinlay and Rowlinson (2002) have instead started to speculate about the limits of this theoretical methodology, its historical soundness and its effectiveness in social theorizing. Furthermore, influenced by Latour, a new group of critics have emerged as supporters of Actor Network Theory and in particular the authors of ANT-history (Durepos and Mills, 2011).

As this brief sprint though the uses of History within OS indicates, the variety of approaches have been richly varied and many OS scholars have shown themselves more than willing to engage with History in some of its myriad forms. The pace has also been relatively rapid. Although Zald could complain in 1996, about the 'incomplete' opening of OS to the humanities (Zald, 1996, p.251), in less than a decade, Clark and Rowlinson in contrast could confidently state that the 'historic turn' in OS was well underway (Clark and Rowlinson, 2004).

Yet, despite this considerable opening up between the two fields, some worrying trends still remain. First the openness is unbalanced - although many examples can be found of OS scholars using History, few can be found of historians applying OS theories, and there is a noticeable lack of willingness by historians working in History departments (rather than business schools) to reciprocate and actively integrate sociological method into their work.

Secondly, despite the comparatively greater use of History within OS, it still has failed to be normalised as an integral part of OS. We feel that is it is significant that, a quarter of a century after initial calls for the historical reorientation of OS that debates still continue to fill 
the journals and conference halls pondering why historical approaches are not more routinely incorporated into OS analyses. Although it has become important for some scholars of OS to think about historical methods, this is far from saying that the usefulness of History has permeated the whole of OS. Applying History to our own analysis, we argue that the roots of these persistent, if weakening, tensions lie in the grand historical battle between History and Sociology. 


\section{2) THE HISTORY OF HISTORICAL SOCIOLOGY}

'Attempts to turn history into a science have been going on for the best part of two centuries now, and show no signs of letting up.' (Evans, 2000, p.45)

Although the poor dialogue between OS and History is commonly regretted within the pages of OS and management journals, what is less often acknowledged is that these modern tensions between the two disciplines are in fact also (intentionally or not) extensions of a debate that has been occurring for the past hundred years between historians and social scientists. In the following section of the paper we outline some of the key elements of this debate, before turning in the next section to a three-point analysis of what we feel to be the key differences of approach. Interestingly, these differences, once analysed quickly seem to crumble and break down to become similarities. This is very revealing of the complexity of the task in hand and shows how paradoxically such disciplinary stereotypes can be simultaneously both very durable and very fragile.

At its very simplest, the task of the historian is to understand the past using particular approaches, or 'tools' to do so. These 'tools' may explicitly reflect the thematic focus of a particular piece of research (e.g. Business History, Women's History), or may explicitly reflect the research interests, be they sociological and/or political, of the writer (e.g. Marxist History, Social History). The key to remember, is that additional to this conscious research focus, authors are also always in turn influenced by certain aspects of the sociological structures of the time in which they write (e.g. see Smith on the essentially masculine identity of the historical discipline, Smith, 1998, esp. p.91, also Vincent, 2005, pp.12, 15). In short, both with knowing it, and without knowing it historians reflect the preoccupations of their age, gender, nationality and contemporaneous context. The dissection of this multiplicity of intentions and influences in writing History is essentially what historiography is. As Budd neatly summarises in his preface to The Modern Historiography Reader: historiography is 'the history of historical writing, not only focusing on what historians have written but also examining how and why historians have thought about the past' (Budd, 2009, p.xiii).

Given this definition it is perhaps surprising that there is not more interdisciplinarity between historians and sociologists. Why is this so? Both disciplines are centrally interested in understanding the motives and the dynamics for collective and individual human behaviours. The historian, like the sociologist, embodies implicitly the concerns of his time, both in terms 
of the wider cultural context in which every individual writes and also in terms of the personal experiences and commitments of each individual. Interestingly, - even if in practice an unobtainable ideal - both disciplines have been warned of the need for a certain degree of detachment in their research practices. Just as sociologists have learned since the Hawthorne studies (amongst others), the importance of detachment and control variables in experiments, historians, as well, have been regularly warned about the need for neutrality and objectivity. Famously Bloch (1954) criticised the ancients, Hérodote and Thucydide for being too concerned and personally involved in the wars they were reporting as historians. As we touch upon to later, in both OS and History there are today schools where subjectivity and closeness to the phenomena of interest are no longer considered a taboo.

The tensions can perhaps be best understood historically. The emergence of historical sociology is commonly said to have come from Germany, particularly from the approach of Gustav von Schmoller (1838-1917). In some ways Schmoller can be seen as firmly moving away from classical historical traditions in his insistence that, even Economic History, could not be determined by strict, universal, mathematically determinable, laws (a proclivity for which can be seen in the early developments of economics specifically, as well as in the Human and Social Sciences more generally). Instead he emphasised the dynamics of the society in which knowledge was produced, influenced by his contemporary economist Carl Menger (1840-1921). Schmoller, some would say, however, remained traditional in his reliance upon archival sources and his assumption that the state had the central role to play in the formation of the economic past and was criticised by Weber for being too descriptive and ultimately not conceptual enough (Weber, 1904).

In terms of finding common ground between the two disciplines, however, the real breakthrough is usually associated with the work of medieval social historian Marc Bloch (1886-1944). Bloch went so far as to suggest that historians and sociologists were working towards essentially the same ends, trying to assess source material only within the context that they were originally written. In 1929, Bloch founded, with colleague Lucien Febvre (18781956), the Annales School (sometimes referred to as the school of total History), marked by the starting of a new scholarly journal, Annales d'Histoire Economique et Sociale, which broke radically with traditional historiography by insisting on the importance of taking all levels of society into consideration. The groundwork had been laid some time before, however, not least through the publication of Febvre's acclaimed examination of the all-embracing influences of culture in Philippe II et la Franche-Comté (1911). Furthermore Bloch believed that, like sociologists, historians should look at the broader structural and social elements that induce 
certain behaviours and events to occur. Perhaps best exemplified in Bloch's study of the Royal Touch [Les Rois Thaumaturges] which was less interested in whether the French King could actually cure scrofula by his touch, or whether it was irrational to believe so, but rather focused on why society believed this at the time and what this said about the relationship of the king to his people and the people to their king (Bloch, 1924).

Bloch's focus was on the longue durée, focusing on the long view of History in terms of the structures of society that cause people to act in certain ways and to believe certain things. What is more, his perspective was one that was keen to embrace all aspects of society and culture as well as the role of the state and the elites, which had been the typical foci of Historywriting before that time. One criticism of the Annales School is that its eagerness to embrace a broader perspective has in fact minimised the individual importance of human agency in history making (something OS scholars are sometimes accused of now). By making all actors in the past reflective of the social structures of their time, minimises explanations that allow for individuals to be truly original, radical or innovative. Nevertheless, Bloch's work marks an important turning point in the reorientation of History to concerns we would now identify as being sociological. His own words sum it up best:

'history is... a science in movement... Now at last, it struggles to penetrate beneath the mere surface of actions, rejecting not only the temptations of legend and rhetoric, but the still more dangerous modern poisons of routine learning and empiricism parading as common sense.' (March Bloch, The Historian's Craft, 1954, p.13)

This debate, which could be essentialised to arguments for integrating the micro with the macro contexts, was mirrored within mainstream social debates. Ontologically both History and Sociology were investigating whether action, change and evolution took place and discussed whether they were pushed from the level of individual behaviour or at higher collective, societal level. According to Mills, in The Sociological Imagination: 'Neither the life of an individual nor the history of a society can be understood without understanding both' (Mills, 1959, p.3).

Amongst historians, also, Bloch was by no means alone and the second generation of the Annales School, dominated by Fernand Braudel (1902-1985), went on to extend his ideas even further. Indeed, Braudel went so far in his book, The Mediterranean and the 
Mediterranean World in the Age of Philip II (1949), to suggest that historical scholars should impose no retrospective boundaries upon the study of History. Time needed to be broadly captured with all of its contingencies (political, social, economic) understood together as if they were alone just single parts of a large symphony orchestra. His theory rejected all structure and preferred to see History as an organic, dynamic, but unpredictable process that should not be narrowly restrained in any way (Braudel, 1958). Furthermore, his work actively attempted to move away from linear, time-orientated nature of History, instead, '[i]n the place of one historical time, they see a plurality of coexisting times, not only among different civilizations but also within each civilization.' (Iggers, 2005, p.56). This move away from linear ideals of 'progress' meant that History, as a grand narrative towards modernity, also began to destabilise. Other sociologist historians emphasised the need to understand social organization and its relationships as the only way to fully understand the past.

Later Historical Sociology was pursued in depth by those such as Immanuel Wallerstein (b.1930), Barrington Moore (1913-2005) and Perry Anderson (b.1938) accompanied by a third wave of Annales devotees, such as Jacques Le Goff (b.1924) and Emmanuel Le Roy Ladurie (b.1929).

Within the world of Sociology, this view was famously extended by Norbert Elias (1897-1990) who (not entirely dissimilarly to Weber before him) broadened sociological perspectives and pushed for a broader, dynamic, multi-dimensional discipline - one that aimed for a 'big picture' of society and its institutions and actors by taking account of the political, the cultural, the economic and the psychological. His vision for Historical Sociology, most famously presented in his analysis of the history of the development of manners and conceptions of a civilized identity since the Middle Ages, The Civilising Process, was one were sociologists would try to break down divisions between the 'natural' and the 'unnatural', the structural and the personal. The individual and society are therefore inseparable. That is, they are different parts of a single whole, incapable of being understood as separate phenomena (Elias, 1939, translated 1994).

Furthermore, Elias, like Weber, advocated a Sociology that was 'value free'- essentially abandoning the preferences or prejudices of the sociologist author. Historical Sociology, according to Elias could only move forward if this neutral and perspective was self-consciously utilised. This aim towards objectivity remains a central difficulty to this day. How can researchers ever truly disassociate themselves from their contemporaneous conditioning, which invariably invades both their interrogative methods and interpretations (Tilly, 1986)? However, sociologists actively took these sorts of debates further via their engagement with History. 
Charles Tilly (1929-2008), for example, argued that 'formal' quantitative method and socialnetwork analysis should be the cornerstone of good historical Sociology (Tilly, 1972, 1981). Tilly's struggles to encourage the revamping of social History to more verifiable, technical research methods of modelling ultimately met with some resistance and as he affirmed in 1986, although advances had undoubtedly been made 'social history has not dissolved into sociology' (Tilly, 1986, p.179)

But despite the fact that significant disjuncture clearly existed between the view points of sociologists and historians, Historical Sociology continued to grow as an important subdiscipline throughout the twentieth century (for example, the journal Comparative Studies in Society and History was founded in 1958). The publication of Philip Abrams book, Historical Sociology (1980), signalled a new maturity in the cross discipline, it both evoked the necessity of sociologists to use more historical approaches, and also warned historians of the problems of over emphasising the role of agency in change and reading sources too literally (Abrams, 1980a). In advocating Historical Sociology he said:

'What I have in mind is a more radical recasting of problems, a deeper and subtler modification of styles of analysis, a more open and through-going recognition of the extent to which in some fundamental respects the two disciplines are trying to do the same thing and are employing the same logic of explanation to do so.' (Abrams, 1980a, p.ix)

So described, the advances that have occurred since Schmoller seem to indicate a degree of amalgamation between the two disciplines since the end of the nineteenth century. Yet perversely the very definition of Historical Sociology as a separate subfield has also served to somewhat ghettoise those with social structuralist and social institutionalist concerns, rather than embracing them as integral and central to the meta-discipline of History as a whole. Still today when sociological articles of a historical bent are presented, a quick look at the reference list usually indicates that scholars cited are more likely to come from Sociology departments then from historical ones (Green and Troup, 1999, pp.110-240, esp. p.110). Furthermore, when History is taught in business schools it is done so separately rather than as a natural part of core courses on management and organizational theory (Booth and Rowlinson, 2006, p.20). 
Similar arguments have been made with regards to the underuse of History within Economics. A recent work (Cesarano, 2006) has observed the evolution of the dialectics between Economic History and economic theory, for example:

'In the past fifty years the advanced tools of economic theory have been deployed in the study of the past, giving rise to the new economic history. Increasing the rigor and consistency of historical inquiry, the new approach has brought substantial progress and a pervasive impact that has reshaped the state of the art. Parallel to these developments, however, economists have steadily lost interest in the subject (McCloskey 1976: 435-7), considering economic history as an applied field confined to specialists, like urban or labor economics, and far removed from the heights of theory.' (Cesarano, 2006, pg 447)

This has undoubtedly been only an overview but it is important to contextualise the relationship of OS and its uses of History against this broader contextual backdrop. In so doing we examine our field relations as stemming from a wider context of debates over the similarities and distinctions between History and Sociology more generally conceived. Only then can we start to become aware of the (sometimes contradictory) metanarratives that mould the intuitive responses of some OS scholars to the claims for the benefits of embracing History. Although the debates between individuals are as multitudinous as they are complex we have nevertheless selected to analyse three main differences of approach that seem (for right or for wrong) to recur time and again in the debates between History and Sociology. 


\section{3) EXPLORING (APPARENT) DIFFERENCES OF APPROACH}

For the purposes of this paper we group the main points of potential methodological differences of approach between the two disciplines into three groups:

(i) The social scientific need for an explicit methodology

(ii) The social scientific ideal of objectivity: a science versus a humanity

(iii) The social scientific priority on practical relevance and applicability

These, we stress, are not the only differences that have been commonly said to exist between so-called 'historical' approaches and so-called 'social scientific' ones, but they do nevertheless represent three of the most frequently-cited differences that we came upon in the course of our research. Indeed, as this section will show, all of these apparent disharmonies quickly break down under scrutiny. Few (if any) modern and reflexive historians or organizational theorists would allow themselves to be described in such absolute terms. We acknowledge, for example, that for every 'objective' social scientist we would be able to find a 'subjective' one (especially in OS!), and likewise few historians would be happy to see their work essentialised as purely subjective, or for that matter objective, in approach. Nevertheless, an examination of these stereotypes is a useful exercise in that it helps to identify some of the persistent prejudices that recurrently present themselves as we explore what the similarities and differences between the disciplines might be.

What we find, in fact, is that both fields can be characterised as much by their contradictions to these three popular assumptions as they can by any adherence to these categorisations of difference. Understanding this, we believe, is an important step towards identifying what lies at the heart of this on-going debate of the difficulty of using History within OS. In our conclusion to this paper we make some propositions as to which additional factors might also influence the cultures of difference between the two fields.

\section{(i) Methodology:}

Perhaps the most frequently cited difference between the two disciplines, and the one underlying many of the tensions of perspective, is the lack of explicit methodology in most History writing as compared to within the Social Science disciplines (Booth and Rowlinson, 2006, p.9). This is usually conceived not so much as a difference in acquiring data (although that was part of it), but chiefly as a difference in terms of the active utilisation - to be precise explicit articulation — of theoretical approaches. Still recently historians would put their hands up and agree that it was fair to say that 'history is an undertheorized discipline, its practitioners 
not generally concerned to explore the methodological foundations of their subject.' (Davies, 2003, p.1).

Few historians have been as adamant as Geoffrey Elton in terms of keeping History free from scientific methods (Elton, 1967). Nevertheless, for the past two hundred years, even despite the post-modernist challenges, most historians remain wedded at some fundamental level to a belief in empiricism, i.e. in the collection of data ('historical evidence') to piece together a story with some degree of verifiable accuracy. Although data is by its very nature subject to interpretation, it still relies on that data existing as a starting point. Taking this line of argument to its logical conclusion, historical documents (or 'relics' as Goldthorpe described them) can be extremely problematic because 'first, they are finite and, second, they are incomplete' (Goldthorpe, 1991, p.213). Although he saw that the possibilities for the interpretation of evidence was of course endless, the ultimate reliance by historians on the chance availability of evidence nevertheless severely restricts the kind of stories that can be told.

And neither did this difference in methodological approach entirely alter to the suggestions of new postmodern ways about thinking of our past that some historians began to explore from the 1960s. As Davies neatly pointed out: 'apparently, the ultimate effect of postmodernism has been to make historians more self-conscious about the methodological underpinnings of their professional practice rather than to bring about any general reassessment.' (Davies, 2003, p.3).

This difference in method has coloured the way journals and research conferences present themselves. Whereas historians are rarely criticised for not specifying their method, for most social scientists method has to be one of the core explicitly stated building blocks to any research project. With the pages of journals the empiricism of many historians can be seen in the extensive footnotes of any article or monograph. While in comparison, the referencing in the Social Science journals seems relatively sparse. Although a historian may of course pursue the justification of a theory as the central intent of their research, they way that they do this is centrally concerned with the presentation of evidence and counter-evidence, (which is not to say that they do not also sometimes simultaneously acknowledge that the historian's own personal, subjective, interpretive lens in turn filters this evidence). Although a source base is used within the Social Sciences it is not relied upon in such a foundational way as in History and there is generally, less self-consciousness parading about the way sources have been interpreted. Indeed, one relatively frequent criticism towards OS and management historians is that although they seem superficially keen to engage with History, they tend to underrate the 
need to engage with the historiography; rarely positioning their findings against the relevant historical literature (Stager, 2006, p.44).

Although OS is a plural and critical discipline, it is still influenced by the dominant international standards pertaining to Social Sciences with regards to research methods and publication rules. For example, in OS and management a relatively low importance is assigned to the publication of monographs. This combined with overcoming the frustrating practicalities such as the limited referencing style of top business journals, might pose very practical difficulties in terms of true co-operation between historians and OS scholars. In short, the practical restraints of research expectations as expressed through the expectations of journals heavily mitigate against historians and OS scholars publishing outside their own immediate fields. As we shall later expand upon, this practical issue does not ultimately hinder the pursuit of cooperation (one simply adjusts to that journal's house style, however odd it might seem compared to the standard practised within one's own discipline), but it does nevertheless serve as a crude indicator of what the differences between the fields might be. Without implying any judgement over relative quality, it does certainly seem that historical journal articles footnote in a much more intensive way than those journals publishing OS studies. Similarly, as far as one can generalise, it is fair to say that History articles only rarely state a methodology upfront.

Beside these factors described above, an additional issue is also important. Historians are trained to use methods (for example, archive analysis, historiographical interpretation) that are not necessarily familiar to OS scholars and are certainly not commonly experienced within most of their academic training. This has meant that, despite the fact that there is an abundant literature on historical methodology (often tailored to specific fields of study), business historians have not devoted much coordinated effort to formalising the way they approach their subject matter of organizations and industries (Wadwani and Bucheli 2013; Rowlinson 2001).

Although it is difficult to pin historians down to a single description of their method, most would agree that the production of historical accounts is achieved through the interpretation of documents and historical facts with both empirical rigour and theoretical insights. Key is the investigation of primary sources (archive work), the selection of them (historical data is not the sum of historical documents), the acknowledgement of hermeneutics (documents need interpretation), the triangulation of sources (sources need to be verified and put in a hierarchy of credibility), the verification of memory gaps or over emphasis (one needs an awareness of the possibility that the past can be either deleted or invented), thick contextualization (events should only be understood in a context), critical analysis of documents (correspondences may be written with tacit objectives) engagement with the historiography 
(showing an awareness of critical approaches that have subsequently been applied to the data by other historians). To be a historian perhaps is to simultaneously apply all of these analytical approaches, or at least some of them. The application of these strands of methodology is too often overlooked in the quest to produce a mere longitudinal analysis or another kind of timefocused study.

\section{(ii) The Ideal of Objectivity:}

As an extension of these debates over the need to explicitly articulate a methodology was the idea that social scientists were somehow more objective and 'scientific' in their approach than historians. So significant is this difference in approach that it has been identified as the base line for the 'embarrassed and defensive relationship between history and theory' (Stedman Jones, 1976, p.298). Hofstadter also neatly summarised this difference of emphasis between History and the Social Sciences based on ideals of scientific credibility:

'There are important and increasingly numerous links between history and social sciences, but the two are also held apart by real differences. Some of these differences arise out of problems of communication or out of institutional arrangements. Others have intellectual substance and among these probably none is so important as a difference over the scientific ideal, by which I mean the belief that the closer social science gets to the methods of the natural sciences, the more perfect it becomes. The prominence of this commitment to science is expressed in our terminology, for when we grow dissatisfied with 'social sciences' we speak of 'policy sciences or 'behavioural sciences' - retaining the noun as a clear testimony to an enduring ideal.' (Hofstadter, 1956 p.366-7)

Émile Durkheim (1858-1917) was one of the first to explicitly describe this rift. As one of the founding fathers of Sociology, he was keen to distance what he saw as the rigorous scientific method of his discipline from that of the dusty, archive-based fact-gathering of the historians. To this end, he adopted the objective language of the Natural Sciences in his sociological works. In his aim to elucidate both present and past social behaviours, he was keen to advocate analytical methods: 'In other words, for Durkheim sociology could offer the 
confident insights to society that psychology offers to individuals' (Budd, 2009, p.203). History, Durkheim felt, was not a science; it was focused only on the particular and was not comparative in approach. If it managed to go beyond these disciplinary strictures it essentially, he argued, 'becomes a branch of sociology' (Durkheim, 1902, p.78). Yet, nevertheless, Durkheim used History, especially historical case studies, to make his arguments about the social meanings generated by social institutions (Durkheim, 1902). The key difference being that he felt his discipline was deductive, aiming to prove a theory through examples from the past. Whereas historians were increasingly trying to let the facts speak for themselves, without any preconceived hypothesis. Durkheim perhaps went too far in stating that if historians started to consider broader, comparative, social factors then they actually became sociologists:

\begin{abstract}
'To produce historians who know how to see historical facts as sociologists do, or -which amounts to the same thing -to produce sociologists who have mastered all of the techniques of history, is the objective which must be striven for on both sides.' (Durkheim, 1902, p.79)
\end{abstract}

There was little consensus however. Durkheim's contemporary, Max Weber (18641920), clearly saw the limitations of this portrayal of History and Sociology as somehow in opposition and preferred a softer dialogue between the two disciplines. Although appointed Professor of Sociology in Germany, Weber always sympathetically positioned himself close to History. He did not, like Durkheim, see Sociology as a purely scientific discipline- claiming rather that motives and meanings were so diverse within society that no truly scientific conclusions could ever be made. Rather than denying the importance and rigour of Sociology, he rather claimed that by understanding the limits of it as a discipline, it could be better utilised in combination with History: an aim that is still pursued by social historians today (Weber, 1922).

Yet, one could also argue that in key ways the arguments for the non-scientific basis of History have been actually strengthened in recent years with post-modern trends emphasising the importance of the philosophical, rather than the scientific, content of History. Following Ludwig Wittgenstein and Bertrand Russell (and popularized by Richard Rorty (Rorty, 1967)) for example, discussions started to consider the 'linguistic turn' ${ }^{3}$, an emphasis that critically

\footnotetext{
${ }^{3}$ A linguistic turn has happened also in organization theory in more than a sub-school.
} 
examined the way that language constitutes our lived realities. Within the discipline of History, Hayden White famously called for the dissection of the language and rhetorical tropes, arguing that historians as writers also have their own subjective, imaginative, and artistic agenda. This is not to deny that facts could be uncovered through the discipline of History, but rather to highlight the ultimately subjective nature of the historian's task (White, 1973). Similarly, Paul Ricoeur (1913-2005) examined the nature of hermeneutics within historiography stressing the need to be aware of the variously constructed narrative realities each historical author presents (Ricoeur, 1984). According to Munslow (2003, p.163) historical knowledge, though found among sources is made of language and narration. Indeed what the past means is not determined by what the past was like but rather by the language of the historian who is talking about it in the present. This position is particularly strongly accepted by the followers of the New History School and their strong narrative linguistic position of rejection of 'empirical fundamentalism' (Munslow, 2003, p.162; p.152).

It was post-modern social theory that most helped move History away from any notions of objectivity. Michel Foucault (1926-1984), for example, famously argued for abandonment of dominant concepts of historical chronology altogether, rather stressing historical events and attitudes primarily as products of different power relations within society. His views ultimately led scholars to deconstruct the process of writing History itself, through acknowledging that even retelling a story was unconsciously a means of exerting power over it. The fact that Foucault has been used so widely by scholars within organizational theory shows that, despite an enduring social scientific pride in objectivity, increasingly OS scholars too see the importance of ever-changing social subjectivities among institutions, organizations and their members. Since the modernist and later post modern and symbolic interpretive turn in organisation theory (Westwood and Clegg 2003), the idea of the existence of general laws governing the best possible ways to organize labour and manage a complex organization irrespective of time, space, culture and power issues, seems to have been entirely abandoned. This is notwithstanding an internal dialectic on this turn such as the critique to the 'ontological turn from a (naive) realist ontology to a socially constructed ontology' (Fleetwood, 2005).

As ever, once under the microscope, the dichotomy between the Social Sciences and the Humanities is much more complicated than it might initially appear. It can be argued that OS is the most plural, critical, humanistic, philosophical among business and management disciplines, and therefore recognises, more than most branches of the Social Sciences, how true objectivity is an entirely elusive aim. Examples can be found, even when the analysis is limited to quantitative datasets, of OS scholars arguing for the need for an historical heuristic viewpoint 
(Eloranta et al., 2010). But nevertheless some fundamental tensions of approach seem to remain between History and OS despite evident self-reassessments within both disciplines. A few approaches within OS actually might have appeared more 'scientific', for example adopting methods and metaphors of biology in search of regularities if not universal laws. Davis argued that:

\footnotetext{
'A more modest ambition for organization theory, then, is an organizational analog of natural history: making comprehensible the developmental pathways of organizations and organizing ex post. This will be unsatisfying for those whose model of social science is physics but is less prone to disappointment due to its imprecision' (Davis, 2010, p.702).
}

Nevertheless it is possible to argue, as has been done by Hofstadter, that History shares with Social Sciences the ability to rigorously describe small-scale phenomena, as well as the bigger contextual picture (Hofstadter, 1956). At this, smaller, level of analysis the disciplines are perhaps closer to what is commonly defined as being 'scientific'.

Although documents can only ever be useful in relation to the quality of the questions asked about them, it should also not be forgotten that more recently, a backlash against some of the post modernist trends can be seen within the academic historical community itself. This is a trend that can be interpreted as also pushing for the importance of the objective foundation stones of History. Without denying some of the usefulness of post modern analysis, Richard Evans famously argued that postmodern preoccupations with the construction of History and the power relationships it embodies and sustains, although useful to a point, have also the potential to damage the core classical objectives of the craft of History (Evans, 2000, p.185; also Marwick, 2001). The contrary could be said to have happened in Organisation Theory where the originally dominant managerial and practical emphasis has faded away with the interest devoted to critical management studies, post modernism and symbolic interpretivism.

Additional to this it has to be said that several branches of History rely squarely on evidence alone again blurring the boundaries that Durkheim identified. Indeed demographic and statistical historians have good justification for their claims to be able to make quantitative as well as qualitative analysis as the numerous specialist journals and conferences of this strong historical sub-discipline can attest (Green and Troup, 1999, pp.141-71). Even the Annales School by the 1930s began to include within its long durée histories Statistical History, Price 
History, and Demographic History (e.g. the work of Camille-Ernest Labrousse (1895-1988), Jean Meuvret (1901-1971)). Calls within History departments were joined by the similar calls of sociologists with an interest in History. Most obviously pertinent to this argument were Charles Tilly's pleas for the abandonment of the false dichotomy between qualitative and quantitative research, and his plea for the more systematic use of 'formal' research methods by social historians. It was only by extending the use of formal methods throughout history (rather than just in certain historical research spheres such as the study of urban areas, labor, social mobility, and collective action) that historical arguments could be truly sharpened and alternative arguments could be ruled out (Tilly, 1972, 1984).

What is immediately evident is that claims that premise themselves on the deeply embedded assumptions that OS scholars and other social scientists are purveyors of theory, while historians are constructors of necessarily subjective narrative accounts, do not easily stand up to close scrutiny. It can be seen that, even in their own histories of field formation, Economics and Sociology also had to struggle to be recognised as so-called objective 'scientific' disciplines. It seems to not be coincidence that the introduction of degree programs in Sociology and Economics happened very late in most European contexts. For example, economics degrees were originally titled 'Civil Economy' to provide a more solid resonance that seemed to echo the titles of degree programmes in the more established sciences, such Civil Engineering (for instance in Italy, Sweden and Denmark).

In short, the arguments between science and non-science, objectivity and subjectivity, seem blurred and difficult to define as being in any sort of definitive opposition. Yet, nevertheless they somehow seem to have influenced, however opaquely, the dialogues that have dominated, both historically and today, the characterisations of difference between the two disciplines. Even a relatively recent paper discussing in highly positive terms the incorporation of historical method into OS betrayed the tendency to slip into dichotomous descriptions highlighting History as primarily narrative and OS as only theoretically driven (Leblebici and Shah, 2004). Somehow, complicated and self-contradictory as these arguments are, they nevertheless seem to be the base line for understanding many of the problems in attempting to integrate OS with History.

\section{(iii) Practical Relevance and Applicability:}

Another key we have identified to define the difference between historians and OS scholars is the differences in weight each discipline employs in terms of assessing the uses to their findings should be put. Again a tension can be discerned. On one hand, historians have 
argued strenuously against using the past to elucidate the present, stating that the differences in contexts, and therefore meanings and values, make such comparisons virtually useless. On the other hand, modern pressure to ascertain, even quantify, the 'impact' of History have increased both public and academic interest in using historical precedents to determine modern priorities. Recent initiatives, such as History and Policy Network (a joint initiative run by University of Cambridge, King's College London and London School of Hygiene and Tropical Medicine) are increasingly arguing for the relevance of History in modern policy choices and thereby campaign against the deep-rooted commitments among historians about the inapplicability of different cultural contexts. ${ }^{4}$

Similarly, historians such as Peter Laslett (1915-2001) have directly applied their History as lessons of practical utility for understanding society today (Laslett, 1965). And others, such as Alan Bullock (1914-2004) have defended the continued relevance of History, arguing that:

\begin{abstract}
'A culture or society that turns its back on the past falls into a cultural and historical amnesia which weakens its sense of identity. For collectively as well as individually, our sense of our own identity is bound up with memory. More than that, a culture or society that turns its back on the past also cuts itself off from the most obvious source of values' (Bullock, 1994)
\end{abstract}

Furthermore, Bullock went on to claim that 'the future is always open, never predetermined, and...we can have a part in shaping it' (Bullock, 1994). But again these arguments over the utility of History are hardly recent and if we cast our eyes back historically we can see that they have always been at the forefront of debates amongst historians themselves. John Stuart Mill is perhaps the most famous proponent of History as a lesson for modern evolution and progress (Mill, 1843, chapter X). Mill's approach is again complex, because in a sense he did use his social philosophy to deploy a sociological approach in an attempt to reconstruct the 'whole organism' of the past (as was more explicitly done by Marx years later), but ultimately he remained of his time, in that he used his utilitarianism to describe distinct phases of social development that culminated in the enlightened present (and, furthermore, contained hope for a progressive future). Similarly, Lord Acton (1834-1902) stressed the moral

\footnotetext{
${ }^{4}$ See: http://www.historyandpolicy.org
} 
responsibility of History as a means of elucidating, our glorious present. Only by recognising the folly of the past can the historian move towards demonstrating the advancement of civilisation (Acton, 1895).

But although exceptions were very articulately expressed, fundamentally, most historians shy against any need to find modern practical applicability for their research, rather arguing that the past should be understood in its own terms. March Bloch, for example, who through advocating a comparative method in historical research (using different approaches to compare across space and time) aimed to free the historical art of making 'presentist' moral judgements. Later, Herbert Butterfield (1900-1979) famously argued that 'the chief aim of the historian is the elucidation of the unlikeness between past and present' (our emphasis, Butterfield, 1931, p.9). The trend continued to the point that it became the dominant perspective amongst historians. In the 1960s Edward Hallett Carr (1892-1982) argued strongly that historians should not judge the past with any modern moral terms (Carr, 1961). While accepting that historians as well as the events they describe are socially determined, he implicitly concluded that History was by its very nature inapplicable in different time periods. To put it concisely: the factors that determined the outbreak of war in one context could never be exactly replicated to necessarily determine the same result in another context. Thereby rendering History essentially useless as a model for developing our present.

At a fundamental level however, Sociology is a science devoted to the study of social phenomena with an implicit mission of contributing to inform policies through understanding, if not directly through action research. The origin of Organisation Theory, with almost all its classic contributions, has been devoted to the understanding of organisational reality with oftenexplicit interest on practical applicability in management and administration. Despite the fact that in the last decades of much Organisational scholarship has actively tried to move away from this tradition with more philosophical and critical theorization, we can argue that the practical relevance and applicability still plays some part in the discipline.

Certainly, the core purpose of Sociology and Organization Theory focuses, not only on the development of knowledge and understanding, but also on the contribution the research may make to the improvement of living and working conditions of human beings (citizens, workers, families) in their social entities (groups, organizations, societies). Why study society if you have no ambitions to improve it? As early as 1989 Zald made the similar point when arguing for the greater use of History in OS. He assumed OS scholar's desire for practical relevance, when he encouraged them that: 'a historically nested, comparative approach to organizations should aid in policy application and formulation' (Zald, 1989, p.83). Indeed, in 
recent times there have been some prominent examples of the practical usefulness of History for the modern workings of organizations (Warren and Tweedale, 2002; Brunninge, 2009). But, even here the divide is not simple and, to be fair, these issues are now often also debated amongst OS scholars, particularly the pitfalls of having a too universalist and/or presentist agenda (Zald 2002; Booth and Rowlinson, 2006). The idea that the past can be used to understand the present (such as exemplified by Weber or Chandler) has also been critiqued within OS (Stager, 2006). Indeed, one of the advantages of pursuing the 'historic turn' in OS is that it makes scholars more aware of these common hazards of seeking relevance in different contexts (Booth and Rowlinson, 2006, p.7). Although there is no present without a past, as Bloch explained, that is far from saying that the past is capable of explaining the present in its entirety (Bloch 1954).

Although many historians and many OS scholars now accord to the dominating fashion to critique 'presentism' there is nevertheless an increasing push in society for History to justify its modern relevance. With this in mind, perhaps the key difference lies in each field's differing levels of defensiveness. Whereas claiming to understanding the present is a way for History to 'prove' its impact, on-going usefulness and applicability, Sociology and Management, instead, have a long confident tradition of providing analyses for the present and with being in close contact with the object of study (the firm, the employees etc.). In short, whether right or wrong, sociologists have comparatively less anxiety about publicly justifying their relevance and usefulness to tax-paying society.

Encouragingly, this analysis has shown that there are many points of potential collaboration between historians and OS scholars. Indeed, all of the three points we make about so-called fundamental differences seem to be ones that have been recognised and debated within the disciplines themselves. For every example of a difference, inconsistencies were found. While some historians have remained wedded to the necessarily subjective basis of their discipline, others have rigorously advocated the application of more scientific methods. Whereas some have argued for the impossibility of using historical research as a means of better understanding the present and the future, others have argued that this is indeed the point of History and so on and on. But although this analysis has highlighted many commonalities of interests and approaches the very fact that the debate still exists - and that such crude generalisations can be made-is representative, we believe, of a core consciousness that historians and sociologists are doing, and should be doing, slightly different things. Keeping in mind that that there is no need to turn organizational theorists into historians, we now turn to our summary of the practical benefits of using History in OS. 


\section{4) BENEFITS AND OPPORTUNITIES}

Going back to perhaps the most vocal proponent of the closeness between History and Sociology, Philip Abrams, perhaps offers the most persuasive reasoning for the need to actively work towards the interdisciplinary integration of History and Sociology.

'...history and sociology are effectively the same enterprise. Both seek to understand the puzzle of human agency and both seek to do so in terms of the processes of social structuring. Both are impelled to conceive of those processes both chronologically and logically, as both empirical sequence and abstract form; in this context neither the diachrony-synchrony distinction nor the ideographic-nomothetic distinction carry weight. Sociology must be concerned with eventuation because that is how structuring happens. History must be theoretical because that is how structuring is apprehended. History has no privileged access to the empirical evidence relevant to the common explanatory project. And sociology has no privileged theoretical aspect.' (Abrams, 1980b, p.5)

Even cynics of this utopian vision, would mostly agree that foundationally speaking there can be no organisations without History, no History without social organisation, and no Sociology without History. Thereby accepting Bloch's universalist perspective of the necessity to relate all things, human or human-made, to their broader originating (and subsequently maturing and changing) social contexts (Bloch 1954). Despite arguing that distinctions between the fields do exist, we too can see that historians and OS scholars have numerous intersecting areas of enquiry - in the formation of institutions, the development of certain types of people, polices and cultures to name just a few. Furthermore, we could argue that since the Industrial Revolution, but in particular in the contemporary age, our world has been dominated by the presence of organisations in every aspect of production, government and private life. This could be said to oblige historians to share with OS, if not the methods, at least the main object of study; organizations, their organised reality and their acts of organising. These meeting points of interest strongly underscore that it would be foolhardy not to also share methods between the two subject areas.

The benefits are palpable. First and foremost, using historical approaches within OS particularly guards against Zald's early complaints in 1989 when he criticised the nomothetic 
approach of OS and the inclination to see their theories as timeless universals, tending to overgeneralise their findings and ignore the possibility of historical alternatives (Zald, 1989, p.101). This is not to say that the field of OS has remained static, or would have remained static, without the insertion of History, but rather to show the additional enrichments that History has brought to OS. History offers the opportunity for OS scholars to critically explore previous contexts and gives them a chance to see how events and philosophies might have been conceived if the circumstances had been different. This benefit has been characterised as the 'antidote to a creeping determinism' that can still be discerned in some Business History and Management Studies (O’Sullivan and Graham, 2010, p.779). Historical perspectives can make OS scholars much more aware of the unplanned nature of the past. For instance the work of Chandler (1977, 1998) or Fligstein (1991) have revealed how business strategy or macro organizational design are often the result of unexpected contingencies or the outcome of unintended effects of state regulation.

Historical perspectives also offer a better understanding of organizational phenomenon by contextualising them in the past. In the words of Sewell, himself a tireless advocate for the need for Social Scientists to pay greater heed to the benefits of historical method: 'time is heterogeneous, that different historical eras have different forms of life and different social dynamics' (Sewell, 2008, p.518). Using History, certainly in the way that a historian would approve, would mean that OS scholars would more regularly go back to the original evidence rather than relying for much of their arguments upon the secondary conclusions of others (O'Sullivan and Graham, 2010, p.779). By going back to the archive OS scholars might be surprised to find that the basis of some central claims within their field are not as clear-cut as is often assumed. For instance an article by Parker and Ritson (2005) provides an example of how an historical work can go back to the past and read a theory in a way different from the current one, which had been taken for granted and enshrined as a kind of 'truth' after decades of indirect narration and reductionist simplification. The works of Hassard (2012), Wilson and McKinlay (2010), and Coke (2006) are examples highlighting the need both to contextualize and reinterpret the past.

By accessing the historical evidence, and triangulating these sources with both ahistorical and historical work on organizations and (re)interpreting it themselves, organization scholars distance themselves from derivative work and improve the intellectual dynamism of their field by pushing towards original reassessments. Even if we accept Goldthorpe's argument that historical data is subject to the vagaries of its chance survival, this does not rule out the potential offered by revisiting the data that does survive (Goldthorpe, 1991). The risk in fact 
lies rather in mis-managing the data or using it in an ahistorical manner, both with regards to understanding academic (Cooke, 2006) or business phenomena (Fligstein, 1991).

Perhaps less frequently argued, the incorporation of History also presents the opportunity for OS scholars to advance quantitatively as well as qualitatively. Although History is commonly praised as important for enriching qualitative understandings of different temporal contexts, we should not forget the very real possibility that accessing new data can greatly supplement contemporary statistics and abstract theoretical claims. This opportunity to collect new data offers the OS scholar the potential not only to expand the scope of applicability of certain OS and management theories, but also to create new ones. A prominent example of how accessing new evidence has contributed to the development of theory can be seen through the work of Chandler. Chandler's detailed History of American corporations has foundationally contributed to defining theories of diversification, integration and organizational design. Thereby using History as a means of defining theories of management.

Last, but certainly by no means least, actively problematizing the rendition of History allows OS scholars to reflect on themselves as critical researchers. This implicitly goes against some of the persuasive claims sometimes made within OS that History can be a good aid to avoid presentism (O’Sullivan and Graham, 2010, p.782). Rather we would claim that the avoidance of presentism, although admirable, is nevertheless an unreasonable task. Try as we might it is impossible to shed our current associations and, like it or not, we are all controlled (admittedly to differing degrees) by the structural limitations of our ontological contexts. We would draw from this conclusion another benefit. Instead of stopping us being presentist, an awareness of History allows us to be at least conscious of the inevitable influences of our own contexts. It helps OS researchers to self-consciously reflect upon themselves and their preoccupations as part of the evolution of the field itself: critically assessing their discipline historically as a cultural and political artefact. For example, self-analysing historically can remind scholars that the research preoccupations of OS reflect the changing research preoccupations within the evolving History of the field. For example, works on labour relations and critiques of capitalism and the changes wrought by the technological innovations came to be fashionable in the 1970s (e.g. Braverman, 1974, Edwards, 1979) were conceived as part of a wider interest in Marxist interpretations of the world. Likewise the stirrings of interest in the use of History in OS that started in the late 1980s and early 1990s (Kieser, 1994, Zald, 1989), should be seen as occurring at a point when the discipline was widening and experimenting with greater dialogue with the humanities, especially with literary theory (e.g. Kaplan, 1986, Martin, 1990; Van Maanen, 1995). Similarly, even the themes elucidated within this paper 
should be seen as part of the twenty first century push by universities, governments and funding agencies to build bridges between disciplines and encourage ways of working together for mutual advantage.

Given these caveats, casting an historical eye over our organizational past, still brings the advantage of making useful comparisons with History. Even if most historians would shy away from any notion that we can usefully learn from the 'lessons' of History, nevertheless most would concede the essential usefulness of comparing to (a subtle distinction to 'learning from') the past. 


\section{CONCLUSION: COOPERATION NOT INTEGRATION}

We can conclude that the diversity of approaches within and between OS and History make possibilities for cross working extremely wide. But this is far from saying that the fields can melt into each other. Although our discussions have mostly elucidated the benefits of using History for OS scholars, of course, the enriching potential for cross-disciplinary fertilisation does not only travel one way. There can be no doubt that Sociology generally (rather more so than OS specifically) has widened and deepened the modern practises of History. Most obviously the incursions of Sociology can be discerned in terms of widening the subjects of historical enquiry away from matters of politics, monarchy and the church to fields such as magic, popular culture, Oral History, Gender History, and the experiences of the 'common' man (look at the works of historians such as Keith Thomas, Laurence Stone and E. P. Thompson for some of the most famous examples). What is interesting was that although historians had been becoming more sociological since the 1950 s, sociologists did not really push to be more historical with the same urgency. This was an unequal trend of influence that has been articulately described within several of the influential publications of Sewell $(2005,2008)$.

Speculation over the roots of this inequality of influence between the two fields is beyond the scope of this paper, but it does point towards a certain amount of healthy disciplinary competition that has long underscored the relationship between History and the Social Sciences. Despite the fact that it is axiomatic to accept that History has shown itself to be open to the adoption of new methods from Sociology, nevertheless it is doubtful that a research paper such as this one would appear within a History journal. Certainly no History conference that we know of would devote a session to the need to better integrate with OS. It could be that this problem of compatibility lies in the very History of the disciplines themselves: perhaps best captured in the image of the old grandfather of History defending itself against its younger, upstart, grandson. Sociology itself only began to be conceived during the second half of the nineteenth century, with the first department of Sociology established at the University of Chicago in 1892. Later it became fashionable for many universities to separate their Social Science and their Humanities faculties: a move that inadvertently made the rift between historians and social scientists even greater. This is surely the biggest contextual factor underpinning the problems we face today. At least a small part of the story we propose reveals that members of the self-confident, long established discipline of History are simply unwilling to bend themselves to be inclusive to the preoccupations of a newer discipline? This defensive stance is explicable, particularly when it found itself faced with the 'high degree of intellectual imperialism' paraded by social scientists (Leblebici and Shah, 2004, p.353). Especially 
defensive when directly criticised by eminent sociologists, such as Herbert Spencer (18201903), who claimed that Sociology, as the more rigorous, more applicable discipline, stood to History 'much as a vast building stands related to the heaps of stones and bricks around it' (Spencer, 1904). Thus described, the differences partially lie in the evolution of the disciplines themselves. An evolution along different paths that now expresses itself practically in terms of the different disciplinary expectations of the different peer groups to which historians and OS scholars necessarily have to speak. Indeed, the splintering of disciplines into a variety of specialisations (which consequently might then compete) can be seen as part of the evolution of many branches of academic and professional specialism.

Additionally, while the OS scholar is keen, to understand the multifarious factors influencing the way institutions work and very open to a plurality of methodologies and sub schools, the historian, even if equally open, by definition has to always look over his shoulder and place his findings in the retrospective context. Simple as this may sound it lies nevertheless at the very core of disciplinary difference. Whereas analysing the role of time is the core job of the historian it is a supplementary perspective (all be it a highly desirable one) for the OS scholar. Simply put, at the end of the day, not all OS work relies on situating itself within the temporal perspective. Perhaps it is fair to say that, although different theoretical perspectives are undoubtedly applied in the way historians structure their historical research papers, the ultimate focus on the time perspective results in more of a coincidence between method and discipline in History than exists within OS. For sure, all OS scholars are united in their field of study (organisations, their members' interactions and the organised reality) but the way they approach their research can vary more widely than it generally does in History. We would go as far as to argue that one of the central characteristics of OS is its plurality of methods and its diversity of theoretical perspectives, despite a famous attempt to call for paradigmatic consensus within the field (Pfeffer, 1993). Indeed, according to Hassard, Cox and Rowlinson (2013) it is exactly this 'neophilia' for fashionable organizational topics and new theories that may have cause the trend towards more ahistorical, if not anti-historical, attitudes in the field.

As we hope the main body of this paper has shown, historically the disciplines of Sociology and History have had a highly debated relationship. This lack of historical consensus colours the lack of consensus today, meaning that resistance exists between the disciplines irrespective of the 'reality' of so-called claims for divergences in methodological or ontological approach. 
So where does this lead us to in practical terms? It is telling that even Philip Abrams, the greatest advocate at all for the interdisciplinarity fusion of Sociology and History had to concede:

'...theoretical unity and practical identity are two different matters. And in practice it seems to me that historians and sociologists still have a long way to go in cultivating a common rhetoric that will effectively and adequately express what can readily be seen as their common logic of explanation.' (Abrams, 1980b, p.14)

By extension, although many of the deficiencies of a non-historically orientated OS, such as those that Zald pointed out in 1989, have deep resonance with us, we nevertheless believe that the 'conjoining' of History and Sociology (Zald, 1989, p.87) is not precisely what is required. We disagree that 'history and sociology are and always have been the same thing' (Abrams, 1980a, p.x), rather our views echo those of prominent sociological scholars such as Goldthorpe and Stedman Jones. Goldthorpe understood that the differences between the fields were more of emphasis than of kind - and that the portrayals of History as idiographic and particularizing and Sociology as nomothetic and generalising were too extreme - nevertheless maintained that 'good grounds do still remain for refusing to accept the position that any distinction drawn between history and sociology must be meaningless' (Goldthorpe, 1991, p.212). Sociologists he stated (and by implication, Organizational Theorists) should celebrate the advantages of their discipline: '[i]n other words, sociologists should not readily and unthinkingly turn to history: they should do so, rather, only with good reasons and in full awareness of the limitations that they will thereby face' (Goldthorpe, 1991, p.214).

Stedman Jones made a similar point as early as 1976 when he described History as its own worse enemy in terms of disciplinary self-confidence when it came to defining its theoretical intentions. Rather than History 'borrowing' theory from sociologists as History developed and matured from the 1960s, it needed to define itself in its own terms, creating its own theoretical-historical toolkit of preoccupations and criteria central to its own temporal preoccupations. Seeking a marriage of sociological theory with historical empiricism, argued Steadman Jones, was somehow fundamentally wrong headed and seemed to undermine important boundaries of epistemological integrity (Steadman Jones, 1976, p.296).

We have shown that it is only through understanding the History of Historical Sociology that we can map why certain stumbling blocks present themselves time and again in the 
relationship between OS and History. Although we have found that differences in method, notions of objectivity and practical utility of research findings are not in fact watertight when pushed under the analytical microscope, they nevertheless represent importantly recurrent themes in the History of debates over the potential for alliance between OS and History. Irrespective of their fragility, these debates point us towards commonly perceived dissimilarities and deepen our understanding of the remnants of resistance to historical method within some areas of OS. Tensions between OS and History are rooted in some quite unassuming and not so prominently discussed areas of variance. These, as we have alluded to in this section, are largely practical (in terms of the need to orientate to different readerships, different research fora), epistemological (particularly in terms of History's essential need to position itself against the temporal dimension against OS's non-essential one), and historically embedded in the History of the formation of the fields themselves (as part of a longer dialogue about disciplinary commensurability). Based on these findings we conclude that cooperation not integration seems the most sensible line of approach to take in cross-working ventures.

This proposition should not diminish the idea that OS can gain much from using History more widely. Indeed, historians and OS scholars should work closely together, as we have tried to do in the authorship of this paper. This paper posits that being aware of the tensions that have historically underscored the fields of Sociology and History both gives some insights into the futility of quests for a seamless alliance. Ultimately researchers have to plant their commitments in one camp or another - they have to choose where they would like to publish and present their work, and they have to make judgements as to how they self-identify. This is not to say that we cannot make better historians out of OS scholars, but rather to say that, while we can improve their approach to History and even persist in asking them to consider using rather more History, we can also acknowledge that their emphasis and intents are likely to be-and really should be- - subtly different to those of historians.

It may seem counterintuitive for a paper advocating the use of History within OS to warn about too emphatic insistence on integration. But too firm an insistence on what unites OS and History is perhaps as dangerous in the long run as casting them as doomed to eternal conflict. They struggle, we believe, because real and perceived tensions exist. They have moments of complementarity and sometimes moments revealing great gulfs in perception. Although the potential for cross-fertilization is great, the two disciplines can only reach out to each other if they appreciate the chasm of difference that divides them. 
The authors are very grateful to the anonymous reviewers of this paper, to the helpful colleagues who commented on its earlier drafts and to the conveners of the EGOS SWG 08 (Historical Perspectives in Organization Studies), a very fruitful and intellectually stimulating environment.

\section{Anna Greenwood}

Associate Professor of Colonial History, The University of Nottingham, 199, Taikang East Road, Ningbo, 315100, Zhejiang Province, China

Email: anna.greenwood@nottingham.edu.cn

I am Associate Professor of European Colonial History at the University of Nottingham Ningbo China. Previously I was Lecturer in Medical History at the University of Exeter, England (200910) and Lecturer in Imperial History at the University of Strathclyde, Scotland (2005-09). I have published widely on the history of medicine in British imperial possessions, particularly on social and cultural aspects of colonial interchange. My new empirical research focuses on Indian migration to colonial Africa, while my recent theoretical interests lie in the interdisciplinary utilisation of historical methods.

\section{Andrea Bernardi}

Senior Lecturer in Organisation Behaviour, Manchester Metropolitan University, Department of Management, Oxford Road, Manchester M15 6BH, UK

Email: a.bernardi@mmu.ac.uk

I have been Senior Lecturer in Organisational Behaviour at Manchester Metropolitan University since 2012. Prior to that, I worked as Assistant Professor at Nottingham University Business School, China and as Lecturer of Organization Studies at the University of Rome (Roma Tre). My main research interests have included the diversity of the co-operative firm, industrial relations, and occupational health and safety. I am currently working on Chinese cooperatives and on the historical perspective in organization studies. 


\section{REFERENCES}

Abrams, P. (1980a) Historical Sociology. London, Open Books.

Abrams, P. (1980b) “History, Sociology, Historical Sociology”, Past and Present, 87, pp.3-16.

Acton, J. (1895) "Inaugural Lecture: 'On the Study of History”, in Acton, Lord John Emerich Edward, Lectures on Modern History. London, Macmillan, 1930.

Barratt, E. (2011) "Re-Reading C. Wright Mills", Organization, March, pp.1-18.

Beckman, C.M., Burton, M.D. (2008) "Founding the Future: Path Dependence in the Evolution of Top Management Teams from Founding to IPO”, Organization Science, 19 (1), pp.324.

Berger, P.L. and Luckmann T. (1966) The Social Construction of Reality: a Treatise in the Sociology of Knowledge. London, Penguin.

Bloch, M. (1954) The Historian's Craft. Translated P. Putnam, Manchester, Manchester University Press [originally published as Apologie pour l'Histoire ou Métier d'Historien, 1949].

Bloch, M. (1973) The Royal Touch: Sacred Monarchy and Scrofula in England and France translated by J. E. Anderson. London, Routledge and Keegan Paul [originally published as Les Rois Thaumaturges, 1924].

Booth, C., Rowlinson, M. (2006) "Management and Organizational History: Prospects", Management \& Organizational History, Vol 1(1), pp.5-30.

Bourdieu, P. (1990) The Logic of Practice. Stanford, CA, Stanford University Press.

Braudel, F. 1949, La Méditerranée et le Monde Méditerranéen à l'Epoque de Philippe II. Paris, Colin.

Braudel, F. (1958) 'History and the Social Sciences', in Peter Burke (ed.), Economy and Society in Early Modern Europe. London, Routledge, 1972.

Braverman, H. (1974) Labour and Monopoly Capital: The Degradation of Work in the Twentieth Century, New York, Monthly Review Press.

Bruce, K., Nyland, C. (2011) "Elton Mayo and the Deification of Human Relations", Organization Studies, 32, pp.383-405.

Bruce, K. (2006) "Henry S. Dennison, Elton Mayo, and Human Relations Historiography”, Management \& Organizational History, Vol 1(2), pp.177-99.

Brunninge, O. (2009) "Using History in Organizations: How Managers Make Purposeful Reference to History", Journal of Organizational Change Management, 22, pp.8-26.

Budd, A. (2009) The Modern Historiographical Reader. London and New York, Routledge.

Bullock, A. (1994) "Has History Ceased to be Relevant?” The Historian, 43 (104), pp.16-19. 
Burrell, G. (1988) "Modernism, Post Modernism and Organizational Analysis: the Contribution of Michel Foucault" Organization Studies, 9(2), pp.221-35.

Butterfield, H. (1931) The Whig Interpretation of History. London, G Bell.

Carr, E.H. (1961) What is History? London: Penguin Books.

Carroll, G.R., Hannan M.T. (2000) The Demography of Corporations and Industries. Princeton, NJ: Princeton University Press.

Carter, C., McKinlay A., Rowlinson M. (2002) "Foucault, Management and History", Organization, 9(4), pp.515-26.

Cesarano F. (2006), "Economic History and Economic Theory", Journal of Economic Methodology, 13(4), pp.447-67.

Chandler, A.D. Jr. (1998) Strategy and Structure: Chapters in the History of the American Industrial Enterprise. Cambridge, MA, MIT Press.

Chandler, A.D. Jr. (1990) Scale and Scope. Cambridge, MA, Harvard University Press.

Chandler, A.D. Jr. (1977) The Visible Hand. Cambridge, MA, Harvard University Press.

Clark, P., Rowlinson, M., (2004) "Treatment of History in Organization Studies: Towards an “Historic Turn”?" Business History, 46, pp.331-52.

Clegg, S., Bailey, J.R., (2008) International Encyclopedia of Organization Studies, Sage Publications.

Clegg, S. (1998) Foucault, Power and Organizations in McKinlay A. and Starkey K., (eds) Foucault, Management and Organization Theory. London, Sage, pp.29-48.

Clegg, S.R., Higgins W., (1987) "Against the Current: Organizational Sociology and Socialism”, Organization Studies, 8, pp.201-21.

Cooke, B., (2006) “The Cold War Origin of Action Research as Managerialist Cooptation”, Human Relations, 59, 5, pp.665-93.

Costea, B., Crump N., Holm J., (2006) "Conceptual History and the Interpretation of Managerial Ideologies”, Management \& Organizational History Vol 1(2), pp.159-75.

Cunliffe, A.L., Luhman, J.T., Boje, D.M. (2004) "Narrative Temporality: Implications for Organizational Research", Organization Studies, 25(2), pp.261-86.

Czarniawska, B. (1998) A Narrative Approach to Organization Studies. Qualitative Research Methods Series Vol. 43. Thousand Oaks, Ca., Sage Publications.

David, P.A. (1985) "Clio and the economics of QWERTY”, American Economic Review, 75 (2), pp.332-7.

Davies, S. (2003) Empiricism and History. Bristol, Palgrave. 
Davis, G.F. (2010) “Do Theories of Organizations Progress?”, Organizational Research Methods, 13, pp.690-709.

Douglas, M. (1987) How Institutions Think. London, Routledge.

Durepos, G., and Mills, A.J., (2011) “Actor-Network Theory, ANTi-History and Critical Organizational Historiography", Organization, September, pp.1-19.

Durkheim, É. (1902) 'History, Function and Cause', in Selected Writings, Trans. Anthony Giddens. Cambridge University Press.

Edwards, R. (1979) Contested Terrain: The Transformation of the Work-Place in the Twentieth Century, New York, Basic Books.

Elias, N. (1994) The Civilizing Process: The History of Manners and State Formation and Civilization, Vols I and II, Oxford, Blackwell [first published as Über den Prozess der Zivilisation, 1939].

Elton, G.R. (1967) The Practice of History, London, Methuen.

Eloranta, J., Ojala, J., Valtonen, H. (2010) "Quantitative Methods in Business History: An Impossible Equation?”, Management \& Organizational History, Vol. 5(1), pp.79-107.

Engwall, L. (1992) Mercury Meets Minerva. Oxford, Pergamon Press.

Evans, R.J. (2000) In Defence of History. London, Granta Books [first pub. 1997].

Fleetwood, S. (2005) "Ontology in Organization and Management Studies: A Critical Realist Perspective", Organization, Volume 12 (2), pp.197-222.

Fligstein, N. (1991). The structural transformation of American industry: an institutional account of the causes of diversification in the largest Wrms, 1919-1979. In W. W. Powell \& P. J. DiMaggio (Eds.), The new institutionalism in organizational analysis (pp. 311-336). Chicago: University of Chicago Press.

Foster, W. M., Suddaby, R., Minkus, A., Wiebe E. (2011) "History as Social Memory Assets: The Example of Tim Hortons", Management \& Organizational History, 6 (1), pp.10120.

Gherardi, S., Strati A. (1988) "The Temporal Dimension in Organizational Studies", Organization Studies, 9, pp.149-64.

Goldthorpe, J. (1991) "The Uses of History in Sociology: Reflections on some Recent Tendencies", British Journal of Sociology, 42, pp.211-30.

Green, A., Troup K. (1999) The Houses of History: A Critical Reader in Twentieth Century History and Theory. Manchester University Press.

Greiner, L. (1972) "Evolution and Revolution as Organizations Grow", Harvard Business Review, 50, 4, pp.37-46. 
Hannan, M.T., Freeman, J. (1977) “The Population Ecology of Organizations", American Journal of Sociology, 82 (5), pp.929-64.

Harrison, R.J., and March, J.G. (1986) "Decision Making and Post-Decision Surprises", Administrative Science Quarterly, 29 (1), pp.26-42.

Hassard, J. (1993) Sociology and Organization Theory: Positivism, Paradigms and Postmodernity. Cambridge: Cambridge University Press.

Hassard J. (2012) "Rethinking the Hawthorne Studies: The Western Electric Research in its Social, Political and Historical Context", Human Relations, 65, pp.1341-461.

Hassard, J. Wolfram Cox, J. \& Rowlinson, M. (2013) "Where are the Old Theories of Organization? Prospects for Retrospection in Organization Theory", Academy of Management Review, 38 (2), pp.309-13.

Hinings, C.R. (2010) “Thirty years of Organization Studies: Enduring Themes in a Changing Institutional Field”, Organization Studies, 31, pp.659-75.

Hofstadter, R., History and the Social Sciences, chapter 9, in Stern F.R. (ed.), (1956) The Varieties of History: from Voltaire to the Present. New York: Meridian Books.

Hoskin, K. (2004) "Spacing, Timing and the Invention of Management", Organization, 11, pp.743-57.

Iggers, G. (2005) Historiography in the Twentieth Century: From Scientific Objectivity to the Postmodern Challenge. Middletown, Connecticut, Wesleyan University Press [first published, 1997].

Jensen, M.C., Meckling W.H. (1976) “Theory of the Firm: Managerial Behavior, Agency Costs and Ownership Structure", Journal of Financial Economics, 3, pp.305-60.

Kaplan, T.J. (1986) “The Narrative Structure of Policy Analysis”, Journal of Policy Analysis and Management, 5, pp.761-78.

Kieser, A. (1994) "Why Organization Theory Needs Historical Analyses and How this Should be Performed", Organization Science, 5 (4), pp.608-20.

Laslett, P. (1965) The World We Have Lost. London, Methuen.

Leblebici, H., Shah, N. (2004) "The Birth, Transformation and Regeneration of Business Incubators as New Organisational Forms: Understanding the Interplay Between Organisational History and Organisational Theory”, Business History, 46 (3), pp.35380 .

Martin, J. (1990) "Deconstructing Organizational Taboos: The Suppression of Gender Conflict in Organizations", Organization Science, 1, pp.339-59. 
Marwick, A. (2001) The New Nature of History: Knowledge, Evidence, Language. Basingstoke, Palgrave.

Mckinlay, A. (2006) "Managing Foucault: Genealogies of Management", Management \& Organizational History, 1 (1), pp.87-100.

Mill, J.S. (1843) 'The Historical Method', in A System of Logic, Ratiocinative and Inductive, in Robson J.M. (ed.), Collected Works of John Stuart Mill, Volume VIII. Toronto, University of Toronto Press, 1974.

Mills, C.W. (1959) The Sociological Imagination. New York, Oxford University Press.

Munslow, A. (2003) The New History. Edinburgh: Pearson.

Newton, T. (2010) Knowledge and Practice: "Organization Studies within a Historical and Figurational Context”, Organization Studies, 31, pp.1369-95.

O’Sullivan, M., Graham, M.B.W. (2010) “Moving Forward by Looking Backward: Business History and Management Studies”, Journal of Management Studies, 47 (5), pp.775-91. Parker L.D. Ritson P.A. (2005), "Revisiting Fayol: Anticipating Contemporary Management”, British Journal of Management, 16, pp.175-94.

Pfeffer, J. (1993), "Barriers to the Advance of Organizational Science: Paradigm Development as a Dependent Variable", Academy of Management Review, 18, pp.599-620.

Powell, W.W., DiMaggio P., eds (1991) The New Institutionalism in Organizational Analysis. Chicago, University of Chicago Press.

Ricoeur, P. (1984) The Reality of the Historical Past. Milwaukee, Marquette University Press.

Rorty, R. (1967) The Linguistic Turn: Essays in Philosophical Method. Chicago, University of Chicago Press.

Rowlinson, M. Hassard J. (2011) Historical Methods in Management and Organization Studies, [oral presentation], EGOS, Goteborg.

Rowlinson, M. Booth, C. Clark, P., Delahaye, A., Procter S. (2010) "Social Remembering and Organizational Memory”, Organization Studies, 31, pp.69-87.

Rowlinson, M. Carter C. (2002) "Foucault and History in Organization Studies", Organization, Vol. 9 (4), pp.527-47.

Rowlinson M. (2001) "Business History and Organization Theory", Journal of Industrial History, 4, pp.1-23.

Sales, V. ed. (2003) Les Historiens. Paris, Armand Colin.

Schreyögg, G., Sydow, J., Holtmann, P. (2011) "How History Matters in Organizations: The Case of Path Dependence", Management \& Organizational History, Vol. 6 (1), pp.81100 . 
Scott, R. (2008) Institutions and Organizations. Thousand Oaks, CA, Sage.

Sewell, W.H., (2008) “The Temporalities of Capitalism”, Socio-Economic Review, 6, pp.51737.

Sewell, W.H,. (2005) The Logics of History: Social Theory and Social Transformation, University of Chicago Press.

Shenav, Y. (1999) Manufacturing Rationality: The Engineering Foundations of the Managerial Revolution. Oxford, Oxford University Press.

Smith, B. (1998) 'What is a Historian?' in The Gender of History: Men, Women and Historical Practice. Cambridge MA, Harvard University Press.

Spector, B. (2006) "The Harvard Business Review Goes to War", Management \& Organizational History, 1 (3), pp.273-95.

Spencer, H. (1904) An Autobiography, Vol. 2. London, Williams and Northgate.

Stager Jacques, R. (2006) "History, Historiography and Organization Studies: The Challenge and the Potential", Management \& Organizational History, 1 (1), pp. 31-49.

Starbuck, W.H., Milliken, F.J. (1988) "Challenger: Fine Tuning the Odds until Something Breaks", Journal of Management Studies, 25, 4 July, pp.319-40.

Stedman Jones, G. (1976) "From Historical Sociology to Theoretical History”, British Journal of Sociology, 27 (3), pp.295-305.

Stokes, P., Yiannis, G. (2010) "Engaging with Genocide: the Challenge for Organization and Management Studies”, Organization, 17, pp.461-80.

Sydow, J., Schreyögg, G., Koch J. (2009) “Organizational Path Dependence: Opening the Black Box", Academy of Management Review, 34, pp. 689-709.

Tadajewski, M. (2009) "The Politics of the Behavioural Revolution in Organization Studies", Organization, 16, pp.733-54.

Tilly, C. (1972) Quantification in History, as Seen from France, in Val Lorwin \& Jacob Price (eds)., The Dimensions of the Past, New Haven, Yale University Press, pp.86-117.

Tilly, C. (1981) As Sociology Meets History. New York, Academic Press.

Tilly, C. (1986) “The Tyranny of Here and Now”, Sociological Forum, 1, pp.179-88.

Tilly, C. (1984) "The Old New Social History and the New Old Social History", Review, 7, pp.363-406.

Üsdiken, B., Kieser, A. (2004) "Introduction: History in Organisation Studies", Business History, 46 (3), pp.321-30. 
Üsdiken, B., Kipping, M., Engwall, L. (2011) "Historical Perspectives on Organizational Stability and Change: Introduction to the Special Issue", Management \& Organizational History, Vol. 6 (1), pp.3-12.

Van de Ven, A.H., Poole, M.S. (1995) "Explaining Development and Change in Organizations”, Academy of Management Review, 20 (3), pp.510-40.

Van Maanen, J. (1995) “Style as Theory”, Organization Science, 6, pp.133-43.

Vaughan, D. (1996) The Challenger Launch, Decision, Risk, Technology, Culture and Deviance at NASA. Chicago, The University of Chicago Press.

Vergne, J., Durand, R. (2011) "The Path of Most Persistence: An Evolutionary Perspective on Path Dependence and Dynamic Capabilities”, Organization Studies, 32, pp.365-82.

Vincent, J. (2005) "An Intelligent Person's Guide to History. Gerald Duckworth \& Co Ltd [first published, 1995].

Wadwani R.D. Bucheli M. (2013), Organizations in Time: History, Theory, Methods, New York, Oxford University Press.

Warren, R., and Tweedale, G. (2002) "Business Ethics and Business History: Neglected Dimensions in Management Education”, British Journal of Management, 13, pp.20919.

Weber, M. (1904) Roscher und Knies und die Logischen Probleme der Historischen Nationalökonomie in Gesammelte Aufsätze zur Wissenschaftslehre, Tübingen, J. C. B. Mohr [1968 edition], pp.1-145.

Weber, M. (1922) Basic Concepts in Sociology, Translated H.P. Secher, London, Peter Owen, 1962.

Westwood, R., Clegg, S., eds., (2003) Debating Organizations: Point-Counterpoint in Organization Studies. Oxford: Blackwell.

White, H. (1973) Metahistory: The Historical Imagination in Nineteenth-Century Europe. Johns Hopkins University Press.

Williamson, O. (1985) The Economic Institutions of Capitalism. New York, Free Press.

Wilson J.M. McKinlay A. (2010), "Rethinking the Assembly Line, Organisation, Performance and Productivity in Ford Motor Company, 1908-27”, Business History, 52, pp.760-78.

Wolfram Cox, J. and Hassard J. (2007) "Ties to the Past in Organization Research: A Comparative Analysis of Retrospective Methods", Organization, 14, pp.475-97.

Ybema, S. (2010) "Talk of Change: Temporal Contrasts and Collective Identities", Organization Studies, 31, pp.481-503. 
Zald, M.N. (1989) History, Theory and the Sociology of Organizations in J.E. Jackson (ed.) Institutions in American Society: Essays in Market, Political and Social Organizations, Ann Arbor, University of Michigan Press, pp.81-108.

Zald, M.N. (1993) “Organization Studies as a Scientific and Humanistic Enterprise: Towards a Reconceptualization of the Foundation of the Field", Organization Science, 4(4), pp.513-28.

Zald, M.N. (1996) "More Fragmentation? Unfinished Business in Linking the Social Sciences and the Humanities", Administrative Science Quarterly, 41, pp.251-61.

Zald, M.N. (2002) "Spinning Disciplines: Critical Management Studies in the Context of the Transformation of Management Education”, Organization, 9, pp.365-85. 